\title{
Varietal Evaluation of Vegetable Cowpea [Vigna unguiculata (L.) Walp] with Respect to Plant Growth, Flowering and Fruiting Behavior Under North Gujarat Condition
}

\author{
M. Patel Dipikaben ${ }^{1}$, L.R. Varma ${ }^{2}$ and Shilpa Kumari ${ }^{1 *}$ \\ ${ }^{1}$ Division of Vegetable Science, ${ }^{2}$ Department of Horticulture, S. D. Agricultural University, \\ Sardarkrushinagar, Banaskantha, Gujarat (385 506), India \\ *Corresponding author
}

\section{Key w o r ds \\ Vegetable cowpea, Plant growth, Flowering, Fruiting}

\section{Article Info}

Accepted:

26 June 2018

Available Online:

10 July 2018

\section{A B S T R A C T}

A field experiment was conducted at Horticulture Instructional Farm, Sardarkrushinagar Dantiwada Agricultural University, Gujarat during zaid season 2014. The investigation comprising ten varieties viz., Anand Vegetable Cowpea-1, Dantiwada Vegetable Cowpea2, Kashi Shyamal, Kashi Gauri, Kashi Unnati, Kashi Kanchan, Kashi Nidhi, Arka Garima, Arka Suman and Arka Samridhi were tested in the Randomized Block Design with three replications. Varieties were evaluated on the basis of plant growth, flowering and fruiting characteristics of cowpea. Almost all the growth parameters were significantly influenced by treatments. Treatment V2 (Dantiwada Vegetable Cowpea-2) was recorded maximum plant stand at 20 days (92.59\%) and requires minimum days (5.33) taken for germination. Whereas, treatment V1 (Anand Vegetable Cowpea-1) was recorded higher germination per cent (87.70) and took minimum days (6.66) for commencement of first flower and first picking respectively. Treatment V8 (Arka Garima) was found superior with respect to plant height $(260.97 \mathrm{~cm})$ and number of branches (34.20) at 90 days after sowing. However, Treatment V9 (Arka Suman) performed better with respect to girth thickness of plant $(17.35 \mathrm{~mm})$ at 90 days after sowing. The maximum days (105) for last harvest was recorded with treatment V3 (Kashi Shyamal) and treatment V4 (Kashi Gauri). Whereas, maximum number of picking (8.0) during the crop period was observed in treatment V3 (Kashi Shyamal), treatment V4 (Kashi Gauri), treatment V5 (Kashi Unnati), treatment V6 (Kashi Kanchan) and treatment V7 (Kashi Nidhi). Treatment V10 (Arka Samridhi) was found superior with respect to number of pods per plant (64.66). Whereas, treatment V7 (Kashi Nidhi) was found superior with respect to yield per hectare (155.54 q). To achieve higher yield and maximum return, cowpea variety Kashi Nidhi is superior.

\section{Introduction}

Cowpea (Vigna unguiculata (L.) Walp) is an important leguminous crop is believed to be originated in Central Africa. It is self pollinated annual herb with a wide range of growth habit and response to photoperiod. In country, it is cultivated mainly in Gujarat, West Bengal, Tamil Nadu, Andhra Pradesh, Kerala and Orissa. In Gujarat, it is mainly grow in Sabarkantha, Banaskantha, Mehasana, Patan, Ahemdabad, Kheda and Anand district 
and commonly known as "chowli" in this area. In India, the total area under beans cultivation is about 136 (000 ha) with the production 1373 (000 MT) (Anonymous, 2014-2015). Cowpea is nutritive vegetable and it is an integral part of Indian diet. It is also known as lobia, black-eye pea and southern pea. Their plant tolerates drought, performed well in wide variety of soil and being a legume replenishes low fertility soils when the roots are left to decay. It also grows and covers the ground quickly, preventing erosion. Due to high protein content, resistance to drought, adaptability of different soil types and its ability to improve soil fertility, this pulse crop getting more economic important all over the country. Moreover, its stem and leaves used as animal feed during the dry therefore, its sale also provide additional income to the farmers.

Cowpea is well known for reduce the plasma cholesterol within the body. It is an excellent source of suitable dietary fiber and protein. They also contain steroid compounds called phytosterol. These are very effective for maintaining the standard cholesterol level within the body. Regular usage of cowpea seeds helps to improve the manufacture of the cell which enhances the immunity of the body. Consuming this type of legumes can easily stimulate the entire process of urination. All type of cowpeas which include red, black and light brown is abundant with anti-oxidant qualities. The anti-oxidant properties of cowpea check the growth of cancerous cell within the body.

Cowpea is shallow rooted crop and grown well under low fertile soil and low moisture condition. Thus, it has multipurpose uses and has wide range of adaptability to agro-climatic conditions, prevailing in India. Mostly, cowpea is grown in warm and kharif season in India and often cultivated as intercrop. It is more remunerative with other crops with some saving of fertilizers for higher and profitable yield. It can fix atmospheric nitrogen in the soil by their symbiotic relationship with a specific soil bacteria (Rhizobium spp.). Rhizobium makes atmospheric nitrogen available to the plant by process of nitrogen fixation in their root nodules and thus help for making agriculture more sustainable.

In India, despite the fact that a large number of varieties and agro-techniques have been developed, the productivity of cowpea has still not reached the optimum level. Cowpea is well adapted to arid and semi-arid areas due to its morphological as well as biochemical characteristics. The deep rooted system and its short duration life cycle are some of the factors that make cowpea very adaptable to hostile environments.

Number of superior cowpea varieties are released by different states, universities and ICAR institutes but no study has been carried out with respect to suitability of specific variety of cowpea for certain region. So, there is urgent need to evaluate the cowpea varieties released from states and national levels and made a certain recommendation to generate research evidences of different varieties with respect to their suitability under certain conditions to benefits the cowpea growers of North Gujarat.

\section{Review of literature}

Anjanappa et al., (2000) reported that Arka Komal variety of french bean was recorded the highest plant height $(53.57 \mathrm{~cm})$ followed by Selection-11 $(52.40 \mathrm{~cm})$, Burfi Stringless $(49.22 \mathrm{~cm})$ and Local $(44.94 \mathrm{~cm})$. The cultivar Burfi stringless was recorded the highest number of branches (5.24).

Singh (2000) observed that variety of cluster bean GG-1 has produced taller plants and early maturity as compared to $\mathrm{HG}-75$ and GAUG-9003 at all stages of crop growth, 
significantly higher number of branches per plant over GG-1 but it was statistically at par with HG-75.

Kumar et al., (2000) revealed that commencement of first flower was observed in Arkel variety of garden pea whereas, variety PRS 18-6 was attain maximum plant height $(190.7 \mathrm{~cm})$ and maximum number of branches was recorded with variety LMR6585.

Kumar and Kohali (2001) reported that pea variety Kinnauri is superior with respect to the plant height $(98.93 \mathrm{~cm})$ and nodes of 1 st flower (14.47) than Bonneville.

Kalloo et al., (2005) observed that VR-5 variety of cowpea was performed superior for earliness with respect days to 1st flower (29) and days to 1 st harvest (50). Whereas, variety VR-9 have long crop production period (120) than VR-10 (113). Maximum plant height $(85 \mathrm{~cm})$ was observed with treatment VR-7.

Thakor (2008) revealed that garden pea variety Arkel was found superior with respect to earliness in flowering and early harvesting of marketable pod in comparison to variety Bonneville HFP-4 and KPMR-400.

Futuless et al., (2010) reported that White Kananado variety of cowpea was performed superior in plant height $(190.41 \mathrm{~cm})$ and number of branches per plant (5.62) whereas, the variety White Boron Local was earlier in flowering (38.02 days).

Singh and Singh (2011) observed that garden pea Arkel showed maximum plant height $(48.14 \mathrm{~cm})$ followed by Kashi Mukti (44.98 $\mathrm{cm})$. Whereas, Kashi Mukti produced maximum number of branches (2.86). Maximum germination $(88.58 \%)$ was observed in variety Kashi Udai.
Patel et al., (2011) conducted the field experiment on effect of different plant spacing and varieties on yield parameters of cowpea and they observed that early flowering (36.92 days) was emergence under variety GC-3.

Kumar et al., (2012) reported that the cultivar HG 2-20 variety of cluster bean was superior in plant height $(128.3 \mathrm{~cm})$ followed by HG563 $(120.5 \mathrm{~cm})$ and HG365 (110.2 cm). There were no significant difference in days to maturity and number of branches per plant.

Bhushan et al., (2013) concluded that variety of pea, Early Gaint have maximum plant height $(194.6 \mathrm{~cm})$. Treatment CPS-05-03 and Palam Priya have maximum number of braches (4.3) and number of nodules per plant (77.1) respectively. However, based on the parameter, earliness of flowering measured in terms of days to $50 \%$ flowering in genotype E-6 (60.2) followed by CPS-05-03 (62.7) and DDR-23 (67.7) were recorded to be the mature significantly early when compared with check Bonneville (69.2).

Sharma et al., (2013) reported that garden pea varieties Palam Priya and Azad P-1 have maximum primary branches per plant (26.20) and plant height $(70.45 \mathrm{~cm})$ in comparison to other varieties under experiment. Whereas, significantly maximum pod length $(9.86 \mathrm{~cm})$ and seed per pod (8.98) were observed in garden pea variety $\mathrm{Pb}-89$. Significantly maximum seed yield was noted under Palam Priya (28.23q/ha).

Amin et al., (2014) compared the different varieties of cowpea and out of them, variety AVCP-1 was found superior with respect to growth parameters and they revealed that cowpea varieties Pusa Phalguni and AVCP-1 was produced significantly maximum pods per plant (56) and pod length $(14.9 \mathrm{~cm})$. Whereas, variety JDNVC-74 was found superior with respect green pod yield per hectare (103.5q/ha). 


\section{Materials and Methods}

The experiment was conducted at Horticulture Instructional Farm, College of Horticulture, S. D. Agricultural University Sardarkrushinagar, Dist. Banaskantha, Gujarat in the year 2014-15 to study the Varietal Evaluation of Vegetable Cowpea (Vigna Unguiculata (L.) Walp) with respect to plant growth, flowering and fruiting behavior under North Gujarat condition. The experimental area was medium high land and the soil was sandy to clay loam. Ten varieries viz., AVC-1(V1), DVCP-2(V2), Kashi Shyamal(V3), Kashi Gauri(V4), Kashi Unnati(V5), Kashi Kanchan(V6), Kashi Nidhi(V7), Arka Garima(V8), Arka Suman(V9) and Arka Samridhi(V10) were collected from AAU, SDAU, IIVR and IIHR were tested in a Randomized Block Design with three replications was considered for this study as a test material. Four tones of vermicompost, $20 \mathrm{~kg} \mathrm{~N}, 40 \mathrm{~kg} \mathrm{P}_{2} \mathrm{O}_{5}$ were applied in furrow before sowing of seed. Required quantity of seeds of all the ten varieties was weighed separately for all the experimental plots. The seeds were put into bowl and culture solution was mixed at the rate of $25 \mathrm{gm} / \mathrm{kg}$ for proper coating. After drying in shade, the seeds were used for sowing. Seeds were sown to a depth of 4 to 5 $\mathrm{cm}$ and sowing was done on 22 February, 2014 by dibbling the seeds in the rows which were prepared by sickle before sowing. The seeds were covered properly with the soil. A light irrigation was given immediately after sowing for better germination and then subsequent irrigations were given at morning for about 30 minutes and evening for about 1 hour daily to maintain sufficient moisture in the soil. The following parameters were studied: Yield and Yield Attributes traits viz. Number of pods harvested per plant, Yield of green pods per plant $(\mathrm{g})$, Yield of green pods per plot $(\mathrm{kg})$, Yield of green pods per hectare (q). The data collected were analyzed using Fisher's analysis of variance technique and differences among the various treatments were determined by using least significant difference test at 5\% probability level (Steel and Torrie, 1984). The green marketable pods of cowpea from the border line were picked up first and kept aside. Later on the pods from five selected plants under observations were picked, weighted and counted. Finally, the pods from the net plants were also picked and weighted separately. The green pods of cowpea were picked up continuously at interval of 3-4 days after first picking.

\section{Results and Discussion}

Days taken for germination as performed by different treatments showed marked variation. Significantly early germination of seed was recorded with treatment V2 (Dantiwada Vegetable Cowpea-2) (5.33) which was found statistically at par with treatment V9 (Arka Suman) (6.0), treatment V3 (Kashi Shyamal) (6.33), treatment V5 (Kashi Unnati) (6.33) and treatment V7 (Kashi Nidhi) (6.33). The reason for the early germination is may be due to genetic characteristics of the varieties. These results are in conformity with the findings of Thakor (2008) in vegetable pea and Singh (2000) in cluster bean. Highest germination per cent of (87.70) was observed in treatment V1 (AVC-1) which was statistically at par with treatment V2 (DVCP-2) (81.47\%), treatment V3 (Kashi Shyamal) (79.62\%), treatment V4 (Kashi Gauri) $(73.62 \%)$ and treatment V9 (Arka Suman) (75.07\%). In the present investigation, significant variation in germination per cent among different varieties might be due to difference in their inherent capacity to germinate. This finding is accordance with the Singh and Singh (2011) and Sharma et al., (2013) in garden pea. It is obvious from the data showed that the effect of different treatments on plant stand at 20 days after sowing (\%) was found to be nonsignificant. However, the maximum plant stand $(92.59 \%)$ was recorded with treatment V2 (Dantiwada Vegetable Cowpea-2) (Table $1)$. 
Table 2 refers the performance of different varieties on plant height $(\mathrm{cm})$, number of branches, Girth thickness at 90 days after sowing $(\mathrm{cm})$ : Significantly maximum plant height $(260.97 \mathrm{~cm})$ at 90 days after sowing was recorded with treatment V8 (Arka Garima).This finding is in the accordance with the results of Futuless et al., (2010) and Amin et al., (2014) in cowpea, Singh and Singh (2011) in vegetable pea, Kumar et al., (2012) and Singhal et al., (2014) in clusterbean and Patel et al.,(2013) in green gram. Maximum number of branches at 90 days (34.20) was observed in treatment V8 (Arka Garima). This type of varietal difference was also reported by Singh (2000) in clusterbean, Futuless et al., (2010) and Amin et al., (2014) in cowpea, Singh and Singh (2011) in vegetable pea and Patel et al., (2013) in green gram. Maximum girth thickness of plant at 90 days $(17.35 \mathrm{~mm})$ was observed with treatment V9 (Arka Suman) but it was statistically at par with treatment V8 (Arka Garima) (16.83 mm), treatment V4 (Kashi Gauri) $(16.17 \mathrm{~mm})$ and treatment V6 (Kashi Kanchan) (15.99 mm). Significant variation in plant height, number of branches and girth thickness at 90 days among different varieties might be due to difference in their genetical setup. Khan et al.,(2013) in pea observed the similar result.

Table 3 refers performance of different varieties on days taken for commencement of 1 st flower, days taken for 1st picking, days taken for last picking and number of pickings during the crop period: Significantly early flowering (46.00) was observed with treatment V1 (Anand Vegetable Cowpea-1) which was significantly at par with treatment V9 (Arka Suman) (47.33), treatment V2 (Dantiwada Vegetable Cowpea-1) (47.66) and treatment V6 (Kashi Kancha) (47.66). It is due to the inherent characters of variety. These results are in conformity with the findings of Patel $e t$ al., (2011) and Futuless et al., (2010) in vegetable cowpea and Kalloo et al., (2005) in vegetable pea. Minimum days for first picking after sowing (61.00) was observed under treatment V1 (Anand Vegetable cowpea -1) but it was significantly at par with treatment V6 (Kashi Kanchan) (63.00) and treatment V9 (Arka Suman) (63.00).

Table.1 Performance of different varieties on days taken for germination, per cent germination and plant stand at 20 days after sowing (\%)

\begin{tabular}{|c|c|c|c|}
\hline Treatments (Varieties) & $\begin{array}{l}\text { Days taken for } \\
\text { germination }\end{array}$ & Per cent germination & $\begin{array}{l}\text { Plant stand at } 20 \text { days } \\
(\%)\end{array}$ \\
\hline v1 & 6.66 & 87.70 & 87.03 \\
\hline v2 & 5.33 & 81.47 & 92.59 \\
\hline v3 & 6.33 & 79.62 & 88.88 \\
\hline v4 & 6.66 & 73.62 & 85.18 \\
\hline v5 & 6.33 & 57.96 & 85.18 \\
\hline v6 & 6.66 & 61.66 & 85.18 \\
\hline v7 & 6.33 & 68.51 & 87.95 \\
\hline v8 & 7.66 & 69.44 & 87.03 \\
\hline v9 & 6.00 & 75.07 & 89.81 \\
\hline v10 & 6.66 & 69.51 & 87.03 \\
\hline S.Em. \pm & 0.36 & 4.90 & 3.27 \\
\hline C.D. at 5\% & 1.08 & 14.55 & NS \\
\hline C.V.\% & 9.73 & 1171 & 6.46 \\
\hline
\end{tabular}


Table.2 Performance of different varieties on plant height $(\mathrm{cm})$, number of branches, Girth thickness at 90 days after sowing $(\mathrm{cm})$

\begin{tabular}{|c|c|c|c|}
\hline Treatments (Varieties) & plant height $(\mathbf{c m})$ & number of branches & Girth thickness \\
\hline v1 & 66.24 & 29.93 & 15.27 \\
\hline v2 & 81.52 & 19.00 & 14.92 \\
\hline v3 & 167.38 & 24.80 & 15.22 \\
\hline v4 & 123.01 & 27.46 & 16.17 \\
\hline v5 & 86.56 & 21.33 & 12.27 \\
\hline v6 & 83.44 & 28.33 & 15.99 \\
\hline v7 & 63.70 & 20.67 & 13.50 \\
\hline v8 & 260.97 & 34.20 & 16.83 \\
\hline v10 & 104.44 & 29.06 & 17.35 \\
\hline S.Em. & 162.91 & 26.33 & 15.04 \\
\hline C.D. at 5\% & 2.69 & 0.87 & 0.60 \\
\hline C.V.\% & 8.00 & 2.57 & 1.78 \\
\hline
\end{tabular}

Table.3 Performance of different varieties on days taken for commencement of 1 st flower, days taken for 1st picking, days taken for last picking and number of pickings during the crop period

\begin{tabular}{|l|l|l|l|l|l|}
\hline $\begin{array}{l}\text { Treatments } \\
\text { (Varieties) }\end{array}$ & $\begin{array}{l}\text { Days for } \\
\text { commencement } \\
\text { of 1st flower }\end{array}$ & $\begin{array}{l}\text { Days for 1st } \\
\text { picking }\end{array}$ & $\begin{array}{l}\text { Days for last } \\
\text { picking }\end{array}$ & $\begin{array}{l}\text { Number of } \\
\text { pickings }\end{array}$ & $\begin{array}{l}\text { Yield of green } \\
\text { pods/ha (q) }\end{array}$ \\
\hline v1 & 46.00 & 61.00 & 94.33 & 7.33 & 108.69 \\
\hline v2 & 47.66 & 63.67 & 95.33 & 6.66 & 120.57 \\
\hline v3 & 49.00 & 64.66 & 105.00 & 8.00 & 94.41 \\
\hline v4 & 48.66 & 64.33 & 105.00 & 8.00 & 131.41 \\
\hline v5 & 48.00 & 64.66 & 103.33 & 8.00 & 135.21 \\
\hline v6 & 47.66 & 63.00 & 104.66 & 8.00 & 148.69 \\
\hline v7 & 48.33 & 64.33 & 104.66 & 8.00 & 155.54 \\
\hline v8 & 50.66 & 67.00 & 94.33 & 6.33 & 84.66 \\
\hline v9 & 47.33 & 63.00 & 102.33 & 7.66 & 128.02 \\
\hline v10 & 49.33 & 64.66 & 102.33 & 7.33 & 131.20 \\
\hline S.Em.. & 0.67 & 0.89 & 2.10 & 0.41 & 5.19 \\
\hline C.D. at 5\% & 1.99 & 2.66 & 6.23 & NS & 15.42 \\
\hline C.V.\% & 2.40 & 2.42 & 3.59 & 9.52 & 7.26 \\
\hline
\end{tabular}

Variation in days taken for first picking among different varieties could be attributed to its inherent genetic setup and or adoptability to climate and soil condition of this region. Such type of varietal difference was also reported by Singh (2000) in clusterbean, Khan et al., (2012) and Amin et al., (2014) in cowpea. Maximum days for last picking after sowing (105.00) was observed with treatment V3 (Kashi Shyamal) and treatment V4 (Kashi Gauri) and it was statistically at par with treatment V6 (Kashi Kanchan) (104.66), treatment V7 (Kashi Nidhi) (104.66), treatment V5 (Kashi Unnati) 
(103.33), treatment V9 (Arka Suman) (102.33) and treatment V10 (Arka Samridhi) (102.33). Minimum day for last picking after sowing (94.33) was observed with treatment V1 (Anand Vegetable Cowpea-1) and treatment V8 (Arka Garima).

The reason for variation in days taken to last picking among different varieties could be attributed to its inherent genetic setup. Such type of varietal difference was also reported by Amin et al., (2014) vegetable cowpea and Kalloo et al., (2005) in vegetable pea. Different treatments were indicating nonsignificant effect on number of pickings during the crop period. Higher yield of green pod (155.54 q/ha) was recorded with treatment V7 (Kashi Nidhi) and it was statistically at par with treatment V6 (Kashi Kanchan) (148.69 q/ha). These result is corroborate with the findings of Singh (2000) in cluster bean, Sarangi and De (2010) and Ramana et al., (2011) in French bean.

Summary and conclusion of the study are as follows:

Significantly minimum days (5.33) taken for germination and plant stand in field $(92.59 \%)$ were responses by treatment V2 (DVCP-2) and minimum plant stand in field (\%) was recorded with treatment V4 (Kashi Gauri), treatment V5 (Kashi Unnati) and treatment V6 (Kashi Kanchan). Significantly higher percentage of germination $(87.70 \%)$, minimum days (46.00) taken for commencement of 1 st flower and minimum days (61.00) taken for 1st picking were responses by treatment V1 (AVC-1). However, minimum germination per cent was recorded with treatment V5 (Kashi Unnati), maximum days taken for commencement of 1st flower and first picking were recorded with treatment V8 (Arka Garima). Maximum number of picking (8.00) was observed with treatment V3 (Kashi Shyamal), V4 (Kashi
Gauri), V5 (Kashi Unnati), V6 (Kashi Kanchan), V7 (Kashi Nidhi). Significantly maximum plant height $(260.97 \mathrm{~cm})$ and number of branches(34.20) at 90 days respectively after sowing were observed with treatment V8 (Arka Garima) and Whereas, treatment V9 (Arka Suman) was remained superior in girth thickness of plant $(17.35 \mathrm{~mm})$ at 90 days after sowing respectively. Maximum days (105.00) for last harvest was observed in treatment V3 (Kashi Shyamal) and treatment V4 (Kashi Gauri) and minimum days taken for last harvest was observed in V1 (AVC-1) and V8 (Arka Garima). Whereas, significantly maximum number of picking (8.00) during the crop period was observed in treatment V3 (Kashi Shyamal), treatment V4 (Kashi Gauri), treatment V5 (Kashi Unnati), treatment V6 (Kashi Kanchan) and treatment V7 (Kashi Nidhi) and minimum number of pickings recorded with treatment V1 (AVC-1) and treatment V10 (Arka Samridhi). Higher yield of green pod (155.54 q/ha) was recorded with treatment V7 (Kashi Nidhi) and it was statistically at par with treatment V6 (Kashi Kanchan) (148.69 q/ha).

To achieve higher yield and maximum return, cowpea variety Kashi Nidhi is superior but it is statistically at par with variety Kashi Kanchan. Variety Kashi Kanchan is also prominent in protein content and minimum weight loss during the period of marketable shelf life in comparison to variety Kashi Nidhi.

On the basis of above facts, it may be concluded that, for benefits of the farmer and retailers as well as health benefits of consumers, the variety Kashi kanchan is most remunerative and beneficial.

\section{References}

Amin, A.U., Agalodia, A.V. and Prajapati, D.B. (2014) Performance of cowpea varieties 
on growth, yield and quality parameters. Published in state seed committee (2013-2014). CRSS, Jagudan

Anjanappa, M., Reddy, N.Shiva., Krishnappa, K.s., Murali, K. and Pitchaimuthu, M. (2000). Performance of French bean varieties under Southern dry region of Karnataka. Karnataka Journal Agriculture Science 13(2): (503-505).

Anonymous(2014-15). Indian Horticulture Database - 2014.NHB, Ministry of Agriculture, Government of India.

Bhushan, Anil., Singh, B., Singh, A.K. and Singh, Kr. (2013). Evaluation of garden pea genotypes for yield and screening against downy mildew incidence under mid hill conditions of Jammu region. Indian Journal of Plant Genetic Resources 26(2):171-172

Futuless, Ngodi, Kaki., Bake. And Dauda, Ibrahim. (2010). Evaluation of yield and yield attributes of some cowpea (Vigna unguiculata (L) Walp) varieties in Northern Guinea Savanna. Journal of Agriculture Science. 6(12).

Kalloo, G., Rai, Mathura., Singh, Jagdish., Varma, Ajay., Kumar, Rajesh., Rai, G.K. and Vishwanath (2005). Morphological and biological variability in vegetable pea (Pisum sativum L.). Vegetable Science. 32(1):19-23

Kumar, A. and Kohali, U.K. (2001). Evaluation of garden pea genotypes for horticulture traits and resistance against fusarium wilt. Haryana Journal of horticulture Science 30(3\&4):217-219.

Kumar, P., Yadav, V.K., Yadav, A., Saini, L.K., Yadav, S.J. and Kumar, Rameshvar. (2012). Performance of cluster bean cultivars under different resource conservation techniques. Environment \& Ecology. 30(3A): 734-738.

Kumar, Sanjay., Singh, K.P. and Panda, P.K. (2000). Heterosis for green pod yield and its component in garden pea. Haryana Journal of horticulture Science., 29(1\&2):99-101.

Patel, B.V., Parmar, B.R. and Patel, S.R. (2011). Effect of different plant spacing and varieties on yield parameters of cowpea (Vigna unguiculata (L.) Walp.) The Asian Journal of Horticulture. 6(1):56-59.

Sharma, Akhilesh., Sharma, Munish., Sharma, K.C., Singh, Yudhvir., Sharma, R.P. and Sharma, G.D. (2013). Standardization of sowing date and cultivars for seed production of garden pea (Pisum sativum Var. Hortense L.) under north western Himalaya. Legume research, 37(3):287-293.

Singh, J. (2000). Response of cluster bean (Cyamopsis tetragonoloba (L.)Taub) Varieties of different spacing during summer season unpublished M.Sc. (Agri.) thesis GAU, Sardarkrushinagar.

Singh, Rameshwar and Singh, PM. (2011). Effect of sowing date and varieties on yield and quality of garden pea seed. Vegetable Science, 38(2):184-187.

Steel, R.G., Torrie., J.H., 1984. Principles and Procedures of Statistics: A Biometrical Approach, 173-91. McGraw Hill Co. New York.

Thakor, D.P. (2008). Influences of different cultivars and plant spacing on growth, yield and quality of garden pea. Thesis submitted to S.D. Agricultural university.

\section{How to cite this article:}

Patel Dipikaben, M., L.R. Varma and Shilpa Kumari. 2018. Varietal Evaluation of Vegetable Cowpea [Vigna unguiculata (L.) Walp] with Respect to Plant Growth, Flowering and Fruiting Behavior Under North Gujarat Condition. Int.J.Curr.Microbiol.App.Sci. 7(07): 3913-3920. doi: https://doi.org/10.20546/ijcmas.2018.707.455 